\title{
Ryegrass production in Wairarapa, New Zealand: is biological control of Argentine stem weevil important?
}

\author{
M.R. MCNEILL ${ }^{1}$, D.E. HUME ${ }^{2}$, R. ASHBY ${ }^{3}$, M. ASHBY ${ }^{3}$, P. BRANDON ${ }^{4}$, P. GUSCOTT ${ }^{5}$, B. TOSSWILL ${ }^{6}$ and R. BARTON $^{7}$ \\ ${ }^{I}$ AgResearch Limited, PO Box 60, Lincoln, Canterbury, New Zealand \\ ${ }^{2}$ AgResearch Limited, Private Bag 11008, Palmerston North \\ ${ }^{3}$ The Downs, RD 2, Ponatahi Rd, Carterton \\ ${ }^{4}$ Lake Meadows, RD 3, Western Lake Road, Featherston \\ ${ }^{5}$ Gleneden, Ponatahi Rd, Martinborough \\ ${ }^{6}$ Allendale, Woodside Rd, Greytown \\ ${ }^{7}$ Stonestead, RD 1, Underhill Road, Greytown \\ mark.mcneill@agresearch.co.nz
}

\begin{abstract}
To investigate the interaction between Argentine stem weevil (Listronotus bonariensis), its parasitoid Microctonus hyperodae, fungal endophyte (Neotyphodium lolii) and its grass host, four endophyte-ryegrass (Lolium perenne) treatments were established on four farms in Wairarapa in autumn 2003. A diploid ryegrass contained either wild-type or AR1 endophyte or was endophytefree, while a tetraploid ryegrass contained AR1 endophyte. Wild-type, AR1 and endophyte-free ryegrasses average 52\%, $91 \%$ and $2 \%$ endophyte-infected tillers for the 3 years of measurement. Moderate increases over time in the proportion of wild-type infected tillers indicated selection pressures favoured endophyte-infected tillers. Endophyte-free tiller populations were $11 \%$ lower than AR1 or wild-type but not significantly so. L. bonariensis populations were highest in endophyte-free and wild-type pastures and $80 \%$ lower in AR1 pastures. Mean rates of parasitism in L. bonariensis were lower in spring $(9 \%)$ than autumn $(35 \%)$, tended to be higher in wild-type than in AR1 diploid ryegrass, and only had a weak relationship with percent endophyte-infection.
\end{abstract}

Keywords: endophyte, Neotyphodium lolii, Lolium perenne, dry matter yields, plant persistence, Listronotus bonariensis, Microctonus hyperodae

\section{Introduction}

The parasitoid Microctonus hyperodae (Hymenoptera: Braconidae) was first released in New Zealand in 1991 in what was a classical biological control programme targeting Argentine stem weevil (Listronotus bonariensis) (Kuschel) (Coleoptera: Curculionidae). L. bonariensis is a well known pest of ryegrass (Lolium spp.) in New Zealand (e.g. Goldson 1982), adding a significant cost to the pastoral industry (Prestidge et al. 1991). The parasitoid attacks adult $L$. bonariensis, sterilising females and eventually killing the weevil upon the emergence of a parasitoid larva. Between 1991 and 1998, M. hyperodae was widely released in the North Island with more limited releases in the South Island (McNeill et al. 2002). The release of $M$. hyperodae occurred at a time when detrimental livestock welfare issues associated with wild-type endophytes were becoming more unacceptable to the farming community.

The ideal outcome in any classical biological control programme is that pest numbers are reduced to a level whereby any damage is below an economic threshold, although in the case of $L$. bonariensis this has been difficult to establish. While the introduction of the related parasitoid $M$. aethiopoides Loan (Hymenopotera: Braconidae) was singularly successful in reducing damaging populations of Sitona discoideus Gyllenhal (Coleoptera: Curculionidae) (Goldson et al. 1992), in the case of $M$. hyperodae, the expectation was that biological control in conjunction with plant resistance would form part of an integrated pest management approach to managing $L$. bonariensis. Long term research at a release site near Lincoln in the South Island, demonstrated that the parasitoid had caused a significant reduction in first generation adult numbers (Goldson et al. 1998), but did not determine if biological control improved the persistence of the endophyte-free ryegrass in the pasture. North Island research showed similar numerical impacts, with life-tables analyses suggesting a c. $30 \%$ decline in adult numbers as a direct result of biological control (Barker \& Addison 2006).

The advent of new endophytes, with little or no animal toxicity but repellency to L. bonariensis, provided farmers with a new opportunity to improve animal productivity utilising the qualities of ryegrass (Easton et al. 2001; Easton \& Tapper 2005). However, while perennial ryegrass containing AR1 endophyte now form the majority of proprietary seed sown, short-lived Italian and hybrid ryegrasses (L. multiflorum, L. boucheanum), that are generally endophyte-free, are also utilised in pasture production. For these ryegrasses, reducing attack from $L$. bonariensis is dependent on biological control by $M$. hyperodae.

In 2003, a MAF Sustainable Farming Fund trial was established in the Wairarapa region of New Zealand to investigate the performance of ryegrass in an area where $M$. hyperodae had been present since releases in August of 1998. Wairarapa had traditionally been an area where ryegrass yield losses to $L$. bonariensis were significant and rapid (Kain et al. 1977). The main aims of the project were to obtain information from commercial farming operations on plant performance of, and animal growth rates on, new ryegrass-endophyte cultivars. The possibility that the persistence of low endophyte ryegrass had improved in the presence of $M$. hyperodae was also investigated.

\section{Materials and Methods}

\section{Field sites}

The research sites were established in autumn 2003 on four farms in Wairarapa (Table 1). On each farm, four treatments were established consisting of perennial ryegrass (cv. Aries) with either the wild-type or AR1 endophyte, or endophyte-free (nil), and a tetraploid ryegrass (cv. Quartet) with AR1. 'Wildtype' endophyte is the endemic endophyte strain of this cultivar, and through secondary metabolite production (alkaloids) will typically cause ryegrass staggers and reduce animal productivity. AR1 had been inoculated into this cultivar, and, with a different alkaloid profile to wild-type, does not have the same detrimental effects on livestock. Both endophytes produce peramine, the main alkaloid that protects endophyte-infected cultivars from damage caused by L. bonariensis. 
Table 1 Site details for the four study sites in Wairarapa.

\begin{tabular}{llll}
\hline Site & Grid reference & Date sown & Soil type \\
\hline 1 & $41.11448 \mathrm{~S}, 175.56308 \mathrm{E}$ & $24 \mathrm{Mar} 03$ & Kokotau silt loam \\
2 & $41.16807 \mathrm{~S}, 175.25028 \mathrm{E}$ & $12 \mathrm{Apr} \mathrm{03}$ & $\begin{array}{l}\text { Kohinui stony loam/ Opaki brown } \\
\text { stony loam } \\
\text { Wharekaka mottled fine }\end{array}$ \\
3 & $41.14146 \mathrm{~S}, 175.53227 \mathrm{E}$ & $15 \mathrm{Mar} 03$ & sandy loam \\
4 & $41.08661 \mathrm{~S}, 175.40536 \mathrm{E}$ & $22 \mathrm{Mar} 03$ & Tauherenikau stony silt loam \\
\hline
\end{tabular}

At each site, each treatment was allocated to a paddock with a minimum area of 2.3 ha. Sites 1, 3 and 4 were dryland sheep and beef farms and Site 2 a dairy farm. At Sites 1-3, paddocks were fully cultivated then sown, while at Site 4 the pasture was double sprayed with glyphosate then direct drilled. Fertilisers were applied to the paddocks at establishment. Sowing rates for cv. Aries was $16 \mathrm{~kg} / \mathrm{ha}$ and for cv. Quartet ryegrass $21 \mathrm{~kg} / \mathrm{ha}$. All treatments included white clover (Trifolium repens) $\mathrm{cv}$. Challenge ( $3 \mathrm{~kg} / \mathrm{ha})$ and cv. Tahora $(1 \mathrm{~kg} / \mathrm{ha})$. Throughout the course of the study, pasture and stock management was left to the discretion of the farmers. On-farm trials to compare the performance of stock on the four treatments were carried out between the summer of Year 1 and autumn Year 2, but are not reported here. Microctonus hyperodae was released at 12 locations in Wairarapa in 1998 (McNeill et al. 2002) and a survey undertaken in 2002 showed that the parasitoid was established on all four farms. Endophyte contamination was measured in the AR1 treatments. The insect component assessed predominantly adult L. bonariensis and parasitism by $M$. hyperodae.

\section{Ryegrass tiller populations}

Ryegrass tiller populations were determined in spring (October) of Years 1, 2 and 3 and in autumn (April) of Years 2 and 3. Within each paddock, $15 \times 75 \mathrm{~mm}$ diam. cores were taken along a diagonal transect across each paddock with subsequent sampling following a similar route to ensure that cores were collected from the same part of the paddock. Cores were dissected and the number of ryegrass tillers counted.

\section{Endophyte presence and type}

The first sampling for endophyte was first carried out in early summer of Year 1 (16 December 2003), with all 16 paddocks sampled. In summer Year 2, all four treatments from Site 1 were sampled on 16 December 2004 and all treatments except Quartet AR1 were sampled on the remaining sites on 6 January 2005. In mid-summer Year 3 (24 January 2006), all endophyte treatments at Sites 1, 3 and 4 were sampled, with Site 2 sampled in late winter Year 4 (12 August 2006). Since the change in endophyte infection rate from samples taken from Site 2 in August 2006 did not differ significantly from those sites sampled in January 2006, the results were still categorised as Year 3.

Within each paddock, samples were collected across a single transect with 6-10 ryegrass tillers randomly selected around c. 12 collection points. The presence of endophyte was checked using a tissue print immuno-blot assay (Hahn et al. 2003). Contamination of AR1 paddocks with wild-type endophyte was determined by testing endophyte-infected tillers for the presence of the endophyte alkaloid lolitrem B, produced by the wild-type but not AR1. A $3 \mathrm{~cm}$ section from the base of each tiller was freeze-dried and analysed for lolitrem B by HPLC (Gallagher et al. 1985) as outlined by Bluett et al. (2004). For tillers taken in
Years 3 and 4, lolitrem B detection was determined using ELISA as described by Garthwaite et al. (1993) with modifications by Briggs et al. (2007).

\section{Insects}

Adult L. bonariensis were collected in spring (October) and autumn (April) of Years 1, 2 and 3, making a total of six collections. A further collection was carried out in late autumn Year 3 (May 2005) to determine the level of parasitism in the overwintering $L$. bonariensis population. The spring collection represented the reproductive survivors of the over-wintered adult population while the autumn population represented the majority of the L. bonariensis population recruited over the spring and summer prior to going into winter. The autumn population enters photoperiodically induced reproductive diapause and ceases egg laying until spring (Goldson \& Emberson 1980).

Collections of $L$. bonariensis were made using a leaf blower vacuum (Echo $21 \mathrm{cc}$ ) which was used to suck the insects into a removable net recessed into the inlet pipe. Collections were made by dragging the blower vac along a $100 \mathrm{~m}$ transect from within each paddock. Weevils were removed from the litter, counted and parasitism levels determined either by rearing to emergence or dissection (e.g. McNeill et al. 2002). The use of the blower-vacuum did not allow for the determination of $L$. bonariensis density, but provided a relative score of adult numbers among farms and treatments. Other insect pests known to cause damage to ryegrass were also noted during the sampling.

Figure 1 Mean endophyte levels for the ryegrassendophyte treatments measured across the four sites in Wairarapa between December 2003 and January 2006. Error bars represent the $95 \%$ confidence interval.

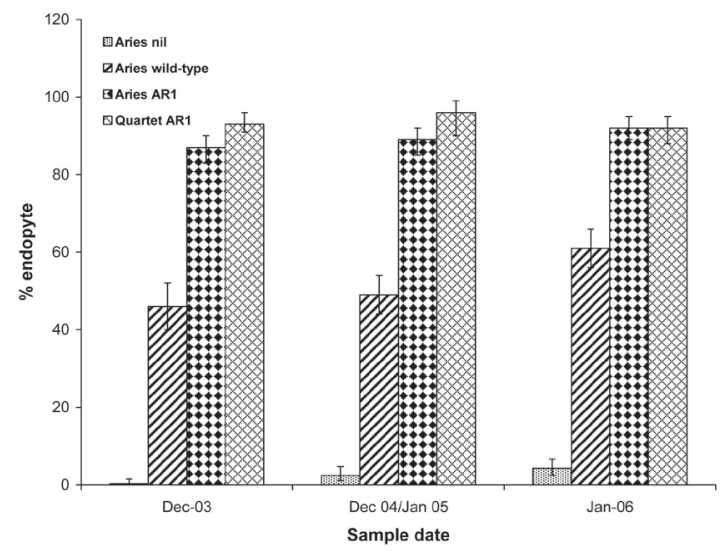


Table 2 Mean ryegrass tillers per $\mathrm{m}^{2}$ for the ryegrass-endophyte treatments measured across four sites in Wairarapa in spring (October) and autumn (April).

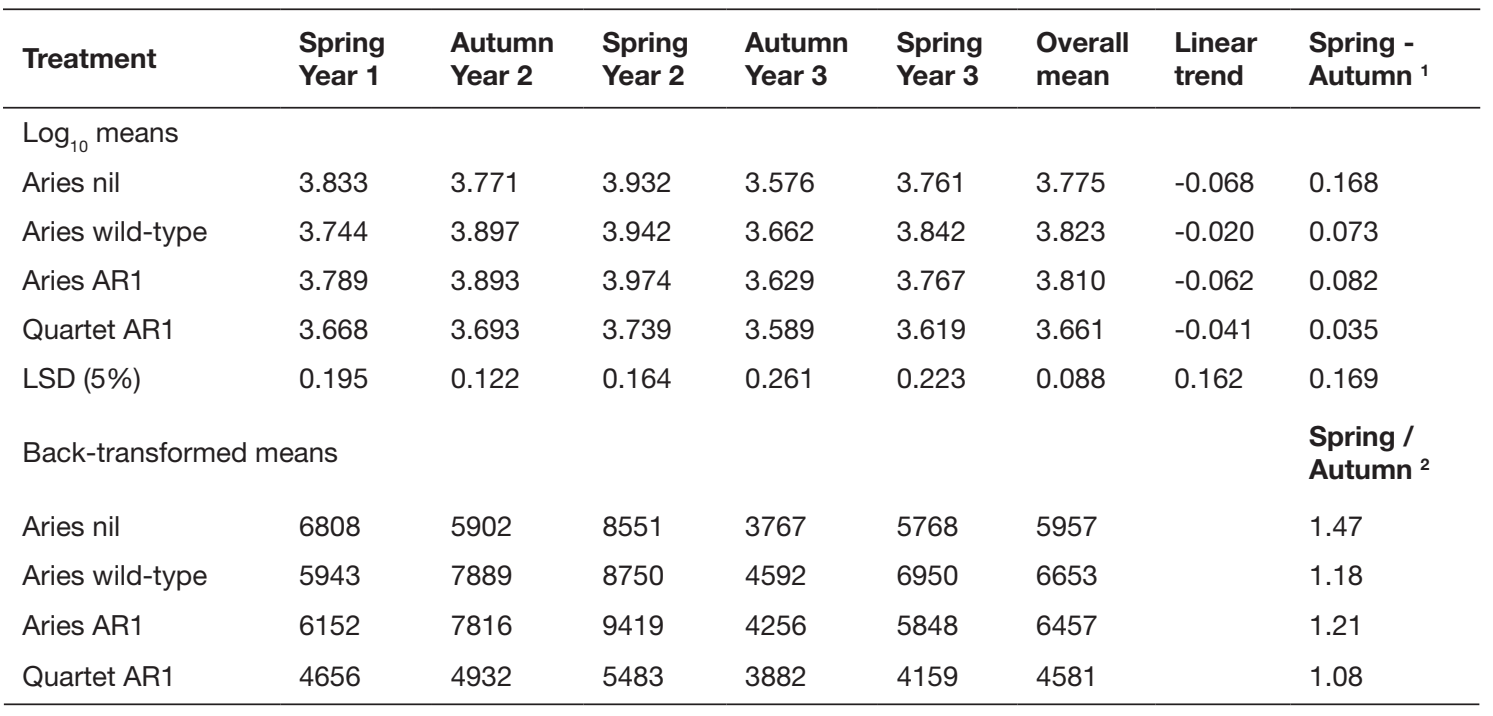

${ }^{1}$ The average of the three spring measurements minus the average of the two autumn measurements provides an indication of seasonal changes in ryegrass density.

${ }^{2}$ Calculated from the average of the spring measurements divided by the average of the autumn measurements.

\section{Meteorological data}

Total monthly rainfall and daily air mean temperature data were obtained from NIWA using meteorological stations based near Masterton, Te Ore Ore (station D05973) and East Taratahi AWS (station D15064).

\section{Statistical analysis}

Ryegrass tiller densities were $\log _{10}$ transformed and analysed by ANOVA assuming a randomised complete block design by treating the four farms as four blocks and the four ryegrassendophyte combinations as four treatments. The mean tiller density over time, the linear trend in tiller densities with time and the average of spring (3) versus autumn (2) densities were calculated (all on the $\log _{10}$ scale) for each ryegrass-endophyte treatment, and these three variables were also subjected to analysis of variance.

Adult L. bonariensis numbers were analysed using a general linear model with a Poisson distribution and log link function. The relationship between adult numbers and percentage endophyte was determined by simple linear regression. Levels of parasitism among sites and ryegrass-endophyte treatments were compared by generalised linear model (GLM) procedure with a logit function and binomial error term (McCullagh \& Nelder 1983). A regression was also carried out to determine the relationship between levels of parasitism in adult $L$. bonariensis collected in May 2005 and the percentage of endophyte-infect tillers. Differences in proportions of endophyte-infected tillers were assessed by calculating $95 \%$ confidence intervals on the binomial data.

\section{Results}

\section{Ryegrass tiller populations}

On average, cv. Aries had 39\% greater tiller populations than
Quartet AR1 ( $\mathrm{P}<0.01)$ (Table 2), although this was not significant at all dates. Aires wild-type and AR1 populations were $12 \%$ and $8 \%$ higher respectively than Aries nil, but this was not significant at any date. There was a general decline in tiller densities over time for all treatments $(\mathrm{P}<0.10)$ but no significant difference among treatments (Table 2). Overall, tiller densities were significantly higher in spring than autumn $(\mathrm{P}<0.01)$ (Table 2), though the only treatment to show a significant seasonal effect was Aries nil.

\section{Endophyte}

The percentage of endophyte-infected tillers in AR1 paddocks was high on all farms at most assessments (Fig. 1), with a mean of $89 \%$ in Aries AR1 paddocks and 93\% in Quartet AR1 paddocks. In contrast, infection rates for Aries wild-type paddocks averaged only $52 \%$ with significant differences among farms (range $46 \%$ to $60 \%$ ). Over all sites, there was a significant increase with time in percent tillers infected with wild-type , $(46 \%, 49 \%$ and $61 \%$ for Year 1, 2 and 3, respectively) (Fig. 1).

For Aries nil endophyte there was only a modest increase in endophyte levels over the study period (Fig 1.). There was a significant site effect, with Site 1 showing a mean endophyte level of $5 \%$, while the ryegrass was free of endophyte at Site 2 and $<1 \%$ at Site 3 . At Site 4 the ryegrass was free of endophyte in Years 1 and 2 but in Year 3,13\% of tillers were infected.

Tests for lolitrem B in endophyte-infected tillers in Year 1 showed there was no or $\leq 2 \%$ contamination with wild-type endophyte in Aries AR1 and Quartet AR1 paddocks at Sites $2-4$. In contrast, at Site 1 in Year 1, 35\% of the endophyteinfected tillers from the Aries AR1 paddock and 14\% of tillers from the Quartet AR1 paddock contained wild-type endophyte. Measurement of these paddocks in Years 2 and 3 showed no significant increase over time (3-year mean of 34\% and $23 \%$ for Aries AR1 and Quartet AR1 paddocks, respectively). 
Table 3 Mean number of $L$. bonariensis \pm SE adults collected from the ryegrass-endophyte combinations in spring and autumn across the four sites in Wairarapa between October 2003 and April 2005 and associated parasitism by M. hyperodae ( $\pm \mathrm{SE})$.

$$
\text { No. of L. bonariensis }
$$

\% Parasitism

$\begin{array}{llll}\text { Spring } & \text { Autumn } & \text { Spring } & \text { Autumn }\end{array}$

$\begin{array}{lcccc}\text { Treatment } & & & \\ \text { Aries nil } & 50.8 \pm 11.56 & 186.8 \pm 27.21 & 12.6 \pm 5.18 & 27.9 \pm 3.15 \\ \text { Aries wild-type } & 35.4 \pm 9.67 & 194.1 \pm 27.7 & 9.9 \pm 5.17 & 39.8 \pm 3.46 \\ \text { Aries AR1 } & 22.8 \pm 7.76 & 24.3 \pm 9.80 & 5.1 \pm 4.62 & 36.1 \pm 8.81 \\ \text { Quartet AR1 } & 25.1 \pm 8.14 & 28.0 \pm 10.54 & 3.7 \pm 3.92 & 50.8 \pm 8.56\end{array}$

Site

1

2

3

4
$129.4 \pm 14.32$

$31.8 \pm 7.09$

$63.9 \pm 10.06$

$28.7 \pm 6.74$
$30.1 \pm 3.35$

$24.2 \pm 5.47$

$36.5 \pm 5.20$

\section{Insects}

L. bonariensis adult numbers were highest in the nil and wildtype endophyte pastures and lowest in the AR1 pastures (Table $3)$. Season had the most significant influence on adult numbers $(\mathrm{F}=52.15, \mathrm{P}<0.001)$ followed by ryegrass-endophyte treatment $(\mathrm{F}=21.27, \mathrm{P}<0.001)$ and site $(\mathrm{F}=20.16, \mathrm{P}<0.001)$. There was also a significant but weak season by treatment interaction $(\mathrm{F}=4.18, \mathrm{P}=0.01)$, due to a $4-5$ times increase in adult numbers in the nil and wild-type pastures between spring and autumn, compared to little change in the AR1 pastures over the same period (Table 3). There was a significant negative relationship between the square root of $L$. bonariensis numbers in autumn and increasing endophyte levels ( $\%$ variance accounted for $=21.2$, $\mathrm{P}=0.007)$. There was no significant relationship between spring L. bonariensis adults and endophyte.

Other ryegrass insect pests observed in localised infestations during the course of the study were grass grub (Costelytra zealandica) (White), porina (Wiseana spp.) and pasture mealybug (Balanococcus poae) (Maskell). C. zealandica was only a problem at Site 2 where it caused sporadic damage to Aries-AR1 pasture.

\section{Parasitism}

Mean rates of parasitism in L. bonariensis in spring (8.7\%) were significantly lower than found in autumn $(35.2 \%)\left(\chi^{2}=35.15\right.$, $\mathrm{P}<0.001)$. Rates of parasitism were highest in Aries wild-type and less in Aries AR1 pastures (Table 3) but the differences for the ryegrass-endophyte treatment were not significant. Mean levels of parasitism did not differ significantly among different ryegrass-endophyte treatments nor among sites $(\mathrm{P}>0.1)$. The levels of parasitism in autumn weevil populations were probably conservative, as parasitism rates tend to increase going into winter. This was reflected in a sample taken in May 2005, where there was a general increase in parasitism at all sites over the April 2005 sample (data not shown) and where parasitism in some of the nil and wild-type ryegrass pastures was $>90 \%$. Regression of percentage parasitism against percent endophyte for May 2005 showed only a weak relationship ( $\%$ variance accounted for $=$ $14.2 \%, \mathrm{P}=0.09$ ).

\section{Meteorological data}

Rainfall over the period March to May 2003, during pasture establishment, was c. $47 \%$ of the long-term monthly average rainfall. Thereafter, rainfall was near to, or greater than, the average monthly rainfall. In the summer period of DecemberFebruary 2003-04, rainfall was on average $200 \%$ of the long-term mean while for the December-February 2004-05 period, rainfall was close to the long-term mean rainfall. Mean temperature over the same period were only noticeably higher in 2005 .

\section{Discussion}

There was wide variation in adult $L$. bonariensis numbers across the four sites, with site 1 generally supporting the highest number of weevils irrespective of endophyte status. This probably reflected the northerly aspect of the trial site and associated warmer temperatures. Numbers were significantly lower in the ryegrass cultivars containing AR1, and there was clear evidence that population recruitment between spring and the subsequent autumn was a lot lower in these pastures. Adult numbers in April (autumn) appeared to be related to the proportion of endophyte-free ryegrass in the pasture, highest in the nil and wild type treatments and lowest in the AR1 ryegrass treatments. The relatively higher numbers of L. bonariensis on wild-type most probably reflected the moderate proportion of endophyte-infected tillers (52\%) in these pastures, as AR1 and wild-type infected ryegrass tillers provide an equivalent high level of feeding deterrence to L. bonariensis adults through the production of peramine (Popay et al. 2003). Furthermore, ryegrass densities measured in this study were far higher than that measured by Barker et al. (1989) in Waikato, but similar to those measured under irrigated pasture in Canterbury (Goldson et al. 1998, McNeill et al. 2001). Therefore, it is highly probable that in the Wairarapa wild-type pastures, endophyte-free tillers were not limiting to L. bonariensis oviposition and subsequent adult recruitment.

While the increase in the proportion of wild-type infected tillers in our Wairarapa study is in keeping with the general phenomena of endophyte-infected tillers being favoured in New Zealand pastures, increases were moderate indicating only relatively mild 
selection pressures at these sites and years. The $11 \%$ difference (although not statistically significant) in tiller populations of between Aries nil and endophyte-infected (AR1 and wild-type), was also in favour of the endophyte-infected ryegrasses. In addition to this, there was no change in the proportion of wildtype endophyte contaminating AR1 pastures at Site 1. Hume \& Barker (2005), summarising reported changes in endophyte levels over time in New Zealand pastures, highlighted the fact that changes over time are not consistent. For example, some sites with a low proportion of tillers infected with endophyte maintained a constant low status while in others there was a significant and rapid increase over time.

In New Zealand, changes in ryegrass persistence and proportions of endophyte-infected tillers are usually closely linked with the severity of insect damage (e.g. L. bonariensis) and degree of drought stress in summer/autumn. In the past, $L$. bonariensis has been a key insect pest driving these changes (e.g. Kain et al. 1977; Francis \& Baird 1989). In field studies on the impact of biological control, Goldson et al. (1998) and Barker \& Addison (2006) reported declines in L. bonariensis populations over time. In particular, Goldson et al. (1998) noted that at a site in Canterbury, the more damaging first summer generation $L$. bonariensis larval peaks declined commensurate with a build-up in parasitism, leading to the suggestion that $M$. hyperodae was significantly reducing adult densities. Furthermore, low adult numbers were observed in a study examining the relationship between endophyte, $L$. bonariensis and its parasitoid $M$. hyperodae (Goldson et al. 2000), leading to the suggestion that parasitism may have suppressed weevil numbers. McNeill et al. (2001) reported a similar result on a dairy farm near Lincoln, where adult numbers were high in the first summer following pasture establishment (c. $128 / \mathrm{m}^{2}$ ) but thereafter, were less than $40 / \mathrm{m}^{2}$.

When conceived, the main aims of this project were to obtain information on the plant performance and animal growth rates that could be expected with the new ryegrass-endophyte cultivars. It also provided an opportunity to determine if the persistence of low endophyte ryegrass had improved in the presence of $M$. hyperodae, the implication being that the parasitoid had perhaps reduced the damage caused by L. bonariensis. The four sites used in this study covered a relatively wide range of environments but a common theme was that the nil-endophyte pastures were maintaining their generally low endophyte levels despite supporting higher L. bonariensis populations when compared with numbers found in the AR1 pastures. Similarly, in the wild-type ryegrass pastures there was not the rapid increase in endophyte status nor tiller loss that perhaps could have been expected to occur as a result of $L$. bonariensis larval damage in the drier east coast regions of New Zealand in the past (e.g. Kain et al. 1977; Francis \& Baird 1989). However, these results showed that in some environments (Site 1), an increase in endophyte levels was associated with high numbers of $L$. bonariensis. Interestingly, this was in Aries wild-type endophyte where between Dec 2003 and Jan 2006 endophyte levels increased significantly from 51 to $70 \%$. In the nil-endophyte pasture at Site 1 , there was no significant change with values of 1 and $4 \%$ recorded from tillers taken over the same time period. Obviously, L. bonariensis is not the only insect that favours endophyte-free ryegrass, with pasture mealybug present at some of these sites and likely to have been providing further selection pressure for endophyte-infected tillers (Pennell et al. 2005).

Biological control of $L$. bonariensis may be successful in improving persistence of endophyte-free pastures in regions of New Zealand where the environment is favourable to the parasitoid and particularly where attack from other pests such as black beetle, pasture mealybug or porina are sporadic or absent. Biological control can also has a positive interaction in high-endophyte pastures, with parasitism of adult $L$. bonariensis in spring reducing oviposition on endophyte infected ryegrass at a time when the peramine concentrations in the leaf lamina are low and the plant is more susceptible to attack (Popay \& Mainland 1991; Ball et al. 1991). In conclusion, it is possible that in regions such as Wairarapa and Canterbury biological control by $M$. hyperodae may attenuate the damage caused by $L$. bonariensis and therefore extend productivity and survival of ryegrass pastures where $L$. bonariensis is the key pest.

\section{ACKNOWLEDGEMENTS}

The authors gratefully acknowledge the technical assistance of John Proffitt, Christine Galbraith and Simon Kelly (AgResearch Lincoln) in the sampling and processing of samples. The efforts of Mark Guscott and Richard Tosswill in managing Sites 3 and 4, respectively, are also acknowledged. Our thanks also to Michael Hickey, Anouck de Bonth, Liz Davies and Amy Watson, (AgResearch Palmerston North) for endophyte testing and David Saville and David Baird (AgResearch Lincoln) for statistical analyses. This work was substantially funded by MAF SFF grant $02 / 124$ : Improved sustainability and quality of ryegrass production in Wairarapa.

\section{REFERENCES}

Ball, O.J.P.; Prestidge, R.A.; Sprosen, J.M.; Lauren, D.R.; 1991. Seasonal levels of peramine and lolitrem B in Acremonium lolii- infected perennial ryegrass. pp 176-180 In: Proceedings of the $44^{\text {th }}$ New Zealand Weed and Pest Control Conference.

Barker, G.M.; Addison, P.J. 2006. Early impact of endoparasitoid Microctonus hyperodae (Hymenoptera: Braconidae) after its establishment in Listronotus bonariensis (Coleoptera: Curculionidae) populations of northern New Zealand pastures. Journal of Economic Entomology 99: 273-287.

Barker, G. M.; Pottinger, R. P.; Addison, P.J. 1989. Population dynamics of the Argentine stem weevil (Listronotus bonariensis) in pastures of Waikato, New Zealand. Agriculture, Ecosystems and Environment 20: 79-115.

Bluett, S.J.; Thom, E.R; Dow, B.W.; Burggraaf, V.T. ; Hume, D.E.; Davies, E.; Tapper, B.A. 2004. Effects of natural reseeding and establishment method on contamination of a novel endophyte-infected perennial ryegrass dairy pasture with other ryegrass/endophyte associations. New Zealand Journal of Agricultural Research 47: 333-344.

Briggs, L.R.; Sprosen, J.M.; Tapper, B.A.; Easton, H.S. 2007. AR1 Quality Assurance by ELISA. pp 289 In: Proceedings of the $6^{\text {th }}$ International Symposium on Fungal Endophytes of Grasses. Eds. Popay, A.J.; Thom, E.R. Grassland Research and Practice Series 13. New Zealand Grassland Association.

Easton, H.S.; Christensen, M.J.; Eerens, J.P.J.; Fletcher, L.R.; Hume, D.E.; Keogh, R.G.; Lane, G.A.; Latch, G.C.M.; Pennell, C.G.L.; Popay, A.J.; Rolston, M.P.; Sutherland B.L.; Tapper, B.A. 2001. Ryegrass endophyte: a New Zealand grassland success story. Proceedings of the New Zealand Grassland Association 63: 37-46.

Easton, S.; Tapper, B. 2005. Neotyphodium research and application in New Zealand. pp. 35-41 In: Neotyphodium in Cool-Season Grasses. Eds. Roberts, C.A., West, C.P., Spiers, D.E. Blackwell Publishing, Ames, Iowa. 
Francis, S.M.; Baird, D.B. 1989. Increase in the proportion of endophyte-infected perennial ryegrass plants in overdrilled pastures. New Zealand Journal of Agricultural Research 32: 437-440.

Gallagher, R.T.; Hawkes, A.D.; Stewart, J.M. 1985. Rapid determination of the neurotoxin lolitrem $\mathrm{B}$ in perennial ryegrass by high-performance liquid chromatography with fluorescence detection. Journal of Chromatography 321: 217-226.

Garthwaite, I.; Miles, C.O.; Towers, N.R. 1993. Immunological detection of the indole diterpenoid tremorgenic mycotoxins. pp. 77-80. In: Proceedings of the 2nd International Symposium on Acremonium/Grass Interactions. Eds. Hume, D.E.; Latch G.C.M; Easton, H.S. AgResearch Grasslands, Palmerston North, New Zealand.

Goldson, S.L. 1982. An examination of the relationship between Argentine stem weevil (Listronotus bonariensis (Kuschel)) and several of its host grasses. New Zealand Journal of Agricultural Research 25, 395-403.

Goldson, S.L; Emberson, R.M. 1980. Relict diapause in an introduced weevil in New Zealand. Nature 286: 489-490.

Goldson, S.L.; Proffitt, J.R.; Baird, D.B. 1998. The bionomics of Listronotus bonariensis (Coleoptera: Curculionidae) in Canterbury, New Zealand. Bulletin of Entomological Research 88: 415-423.

Goldson, S.L.; Proffitt, J.R.; Barlow, N.D. 1992. Sitona discoideus (Gyllenhal) and its parasitoid Microctonus aethiopoides Loan: a case study in successful biological control. In: Pest Control and Sustainable Agriculture. Eds. Corey, S.; Dall, D.; Milne, W., CSIRO, Canberra, Australia.

Hahn, H.; Huth, W.; Schoberlein, W.; Diepenbrock, W. 2003. Detection of the endophytic fungi in Festuca spp. by means of tissue print immunoassay. Plant Breeding 122: 217-222.

Hume D.E.; Barker D.J. 2005. Growth and management of endophytic grasses in pastoral agriculture. pp. 201-226. In: Neotyphodium in Cool-Season Grasses. Eds. Roberts, C.A.; West, C.P.; Spiers, D.E., Blackwell Publishing, Ames, IA.

Kain, W.M.; Ritchie, I.M.; Crouchley, C.G.; Smith, R.G.; Atkinson, D.S.;1977. Effects of stem weevil on grazed swards of perennial ryegrasses in Wairarapa and Manawatu. pp. 192197, 256. In: Proceedings of the $30^{\text {th }}$ New Zealand Weed and Pest Control Conference.

McCullagh, P.; Nelder, J.A. 1983. Generalized linear models. Chapman \& Hall, London. 261 pp.

McNeill, M.R.; Goldson, S.L.; Proffitt, J.P.; Phillips, C.B.; Addison, P.J. 2002. A description of the commercial rearing and distribution of Microctonus hyperodae (Hymenoptera: Braconidae) for biological control of Listronotus bonariensis (Kuschel) (Coleoptera: Curculionidae). Biological Control 24: 167-175.

McNeill, M.R.; Kean, J.M.; Goldson, S.L. 2002. Parasitism by Microctonus aethiopoides on a novel host, Listronotus bonariensis, in Canterbury pastures. New Zealand Plant Protection 56: 280-286.

McNeill, M.R.; Knight, T.L.; Baird, D.B. 2001. Damage potential of Argentine stem weevil in Lincoln dairy pasture: has biological control by $M$. hyperodae altered the balance? Proceedings of the New Zealand Grassland Association 63: 247-254.

Pennell, C.G.L.; Popay, A.J.; Ball, O.J-P.; Hume, D. E.; Baird, D.B. 2005. Occurrence and impact of pasture mealybug (Balanococcus poae) and root aphid (Aploneura lentisci) on ryegrass (Lolium spp.) with and without infection by Neotyphodium fungal endophytes. New Zealand Journal of Agricultural Research 48: 329-337.

Popay, A.J.; Hume, D.E.; Davis, K.L; Tapper, B.A. 2003. Interactions between endophyte (Neotyphodium spp.) and ploidy in hybrid and perennial ryegrass cultivars and their effects on Argentine stem weevil (Listronotus bonariensis). New Zealand Journal of Agricultural Research 46: 311-319.

Popay, A.J.; Mainland, R.A.; 1991. Seasonal damage by Argentine stem weevil to perennial ryegrass pastures with different levels of Acremonium lolii. pp. 171-175. In: Proceedings 44 ${ }^{\text {th }}$ New Zealand Weed and Pest Control Conference.

Prestidge, R.A.; Barker, G. M.; Pottinger, R.P.; 1991. The economic cost of Argentine stem weevil in pastures in New Zealand. pp. 165-170 In: Proceedings of the $44^{\text {th }}$ New Zealand Weed and Pest Control Conference. 